\title{
Rusland: En grå stormagts dilemmaer
}

\section{Af Jens Worning Sørensen}

Rusland er berygtet, frygtet og berømt for sit såkaldte gasvåben at man kan tage en række lande og forbrugere af russisk naturgas som gidsler i internationale konflikter. Men i dag er det russiske gasvåben stærkt overvurderet, Rusland er selv offer for brug af økonomisk magt mod den russiske økonomi, og Ruslands fremtidige muligheder for at opnå indflydelse $\mathrm{i}$ international politik med økonomisk magt står over for en række nye udfordringer og dilemmaer.

I januar 2009 var Sydøsteuropa indpakket i bidende vinterkulde med minusgrader ned mod de 30 . Tirsdag den 6. januar blev det koldere i hjemmene i regionen - fra Ukraine lød det, at Rusland havde stoppet gasforsyningerne gennem Ukraine og dermed gassen til det net, der sender gas til Sydøsteuropa, hvilket kunne mærkes i de hjem, hvis varme er gasbaseret, og flere lande erklærede undtagelsestilstand.
Fra Rusland lød det, at Ukraine stod bag blokaden af gassen - gas blev sendt via Ukraine i de mængder, som Sydøsteuropa havde krav på, men Ukraine tog gassen til sig selv. Forsyningerne beregnet for Ukraine var stoppet, fordi Ukraine ikke betalte sine regninger.

Jeg deltog selv kort tid efter i en parlamentarisk høring om Nord Stream 1 i Sankt Petersborg, hvor parlamentarikere fra de lande, der var omfattet af den miljøundersøgelse, som Espoo-konventionen om transnationale VVM-projekter forskriver, deltog. Her talte Gazprom Exports CEO, Aleksander Medvedev, dunder til forsamlingen af blandt andet vest- og centraleuropæiske politikere og slog fast, at Gazprom, den russiske gasgigant, var en ansvarlig, pålidelig og udelukkende kommerciel - og dermed ikke politisk - aktør i den internationale energiindustri.

Den 18. januar landede Ruslands præsident, Vladimir Putin, og Ukraines

Jens Worning Sørensen er direktør i kommunikationsbureauet Policy Group A/S, udenrigskommentator ved Kristeligt Dagblad samt tidligere generalkonsul i Sankt Petersborg, Den Russiske Føderation. 
Efter det ukrainske statssammenbrud i februar 2014, Ruslands annektering af Krim og begyndelsen på den russisk-ukrainske krig i Østukraine har det russiske gasvåben udviklet sig til et stærkt politisk narrativ, der enkelt iscenesætter Rusland som sikkerhedspolitisk trussel.

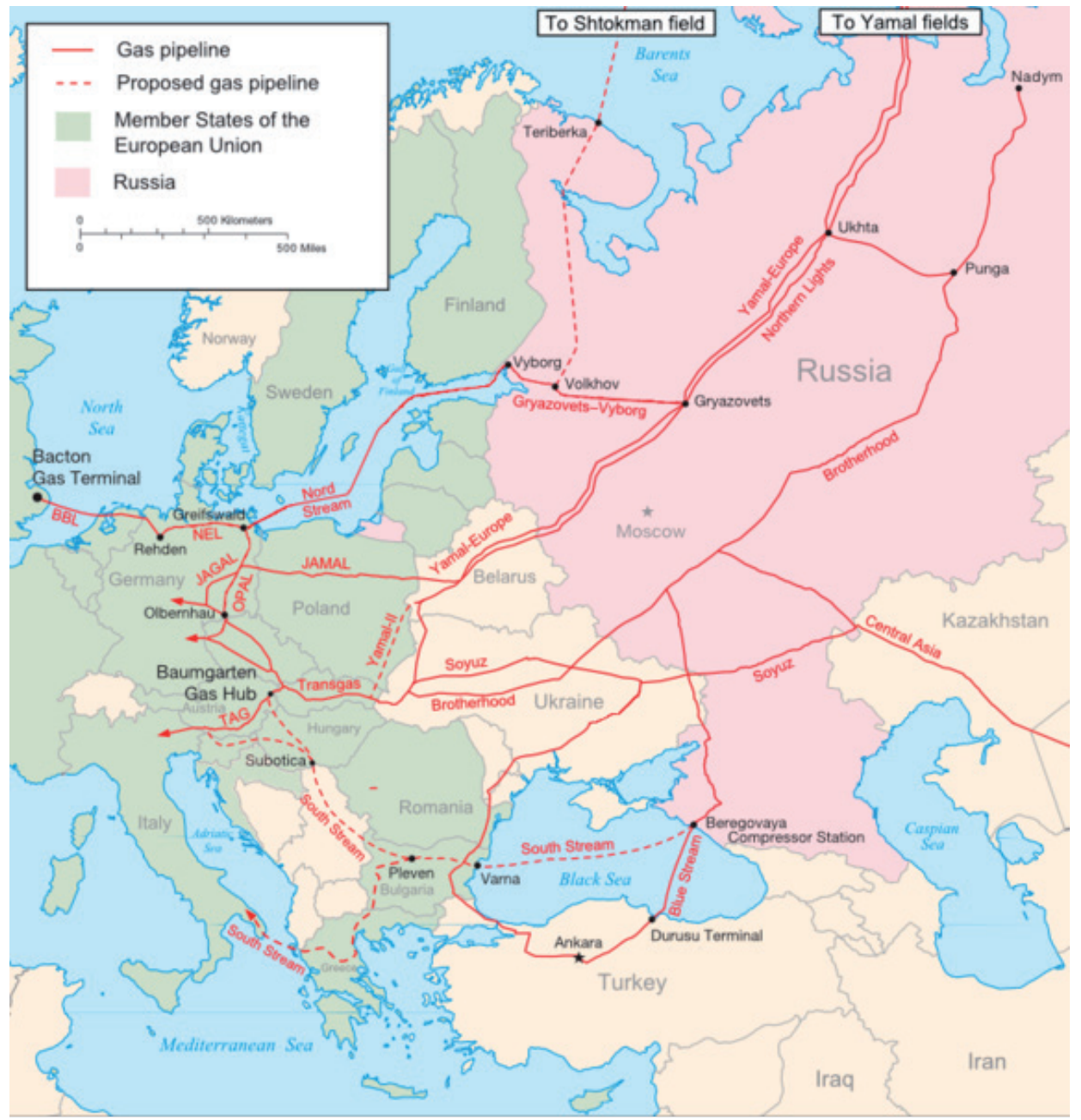

ILL.: Samuel Bailey via Wikimedia Commons

Kort over større eksisterende og planlagte russiske naturgasledninger til Europa 
daværende premierminister, Julia Timoshenko, en aftale, der genåbnede forsyningerne, men i bevidstheden havde sat sig et eftermæle, at Rusland med gassen stod med en jernnæve, der kunne ramme lande afhængige af russisk gas ubarmhjertigt hårdt og tvinge politiske indrømmelser igennem.

\section{Maggi-terninger}

Efter det ukrainske statssammenbrud i februar 2014, Ruslands annektering af Krim og begyndelsen på den russisk-ukrainske krig i Østukraine har det russiske gasvåben udviklet sig til et stærkt politisk narrativ, der enkelt iscenesætter Rusland, som sikkerhedspolitisk trussel, når det handler om energi og forsyning af gas.

Stærke narrativer er en Maggi-terning af virkelighedens mange elementer og dermed også dels en forsimpling af en kompleks problemstilling og dels - og væsentligst - et still-billede af verden på ét bestemt tidspunkt. Problemstillingen er både mere kompleks end som så, og ikke mindst har verden og konteksten for europæisk energisikkerhed ændret sig radikalt siden 2009.

Dykker vi ned i gastvisten mellem Rusland og Ukraine i 2009, der gjorde hjem kolde i Europa, så kan man finde en anden Maggi-terning - Rusland som 'grå stormagt'.

Indtil 2014 har Ruslands og Ukraines mange gastvister handlet om komplekse konflikter, hvor international politik kun var ét og oftest et sekundært og taktisk element. Kon- flikterne involverede både regeringsog præsidentniveauet i de to lande og $i$ lige så høj grad en række magtfulde aktører omkring de to landes energiog transitselskaber, heriblandt magtfulde oligarker.

Her ligger en central del af den 'grå magt' - begge lande bygger på uigennemsigtige og korrupte strukturer formelt som uformelt. Det giver den stærkere, Rusland, en magtposition over for den afhængige, Ukraine.

Vi har set elementer af 'grå magt', som da den dengang nytiltrådte græske premierminister, Alexis Tsipras, kurtiserede Putin i 2015, mens Grækenlands regering var under stærkt pres fra EU og IMF for et økonomisk reformprogram, som Tsipras var imod. Og vi har set det fornylig,

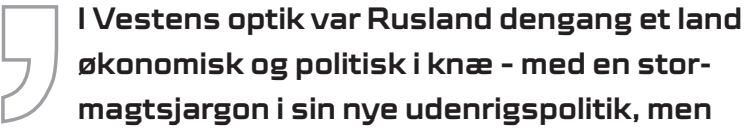
ingen magt at stille bag sine intentioner.

hvor NATO-landet Tyrkiets præsident Erdogan vil købe det russisk anti-missil system $\mathrm{S}-400$.

I begge tilfælde har Rusland noget at tilbyde, og man sammenkæder politiske dagsordner, der er relevante for begge lande. For Tsipras gjaldt det, at han kunne true sammenholdet i EU om sanktioner mod Rusland, en dagsorden der indlysende også var i Putins interesse. Og for Erdogan handler det om at vise styrke i NATO, hvor det for Putin handler om at knytte Erdogan tættere i spillet omkring Syrien.

I begge tilfælde er pointen, at man ved at sammenkæde politiske dags- 
ordner, der intet substantielt har med hinanden at gøre, kan øge den politiske kapital på den mærkesag, man har brug for at styrke over for en tredje part.

\section{Grå magt}

'Grå magt' er en kombination af flere elementer. For det første kræver det stærkt politisk lederskab også institutionelt. Man skal netop inden for en kort tidshorisont kunne sammenkæde politiske dagsordner, der dagen før ikke havde nogen indre sammenhæng. Det set-up passer langt bedre til semi-autoritære, autoritære og populistiske lederskaber end til velfungerende liberale demokratier, hvor alene checks-and-balances på processer vil besværliggøre og forsinke beslutningsgangen.

For det andet forudsætter det evne til at lave komplekse aftaler, der kaster noget af sig til både de involverede lande bilateralt, men typisk også til enkeltaktører omkring disse handler (læs: korruption). Også her dumper velfungerende liberale demokratier, hvorimod Ruslands set-up er noget nær perfekt og meget velegnet, hvis der er en populist eller autoritær ledelse i den modtagende ende.

Og slutteligt omfatter grå magt kapaciteten til at have noget værdifuldt på hylderne - Rusland har gas, olie, en række råstoffer (stort set hele det periodiske system er at finde i Urals, Sibiriens og Fjernøstens gemmer), en globalt konkurrencedygtig militærindustri, atomkraftteknologi, et marked med +140 mio. forbrugere og der-

udover magtfuld international politisk indflydelse i kraft af sin position blandt andet som permanent medlem af FN's sikkerhedsråd.

Ruslands brug af grå magt efter Sovjetunionens sammenbrud følger et spor, der overhovedet ikke er overraskende, og som går på to ben - dels Ruslands udenrigspolitiske prioriteter og dels Ruslands konkrete muligheder for at anvende grå magt, der netop ikke er et globalt anvendeligt instrument.

Da Sovjetunionen bryder sammen, og det nye Rusland tager over under præsident Jeltsins ledelse, er udenrigspolitikken vag og mest præget af krisestyring med fokus på at komme helskindet ud af de internationale konsekvenser af Sovjetunionens opløsning i 15 selvstændige stater. Herunder atomvåbenspørgsmålet, hvor både Rusland, Hviderusland, Ukraine og Kasakhstan nu havde atomvåben.

Det sidste spørgsmål blev internationalt ansvarligt løst ved, at kun Rusland i dag har atomvåben - en proces, der havde et stærkt amerikansk-russisk lederskab. Derudover hang russisk udenrigspolitik lidt og manglede en grundlæggende filosofi, men da Jevgenij Primakov i 1996 ved årets begyndelse afløste den milde Andrej Kozyrev på udenrigsministerposten, kom der andre boller på suppen, og der blev formuleret en række grundlæggende principper, som har 
Siden Wienerkongressen har Rusland følt en medfødt ret til at sidde med ved det største bord, og sådan så også Primakov på den sag, sådan som det udenrigs- og sikkerhedspolitiske establishment i Moskva gør det den dag i dag.

vist overbevisende levekraft til den dag i dag.

I Vestens optik var Rusland dengang et land økonomisk og politisk i knæ - med en stormagtsjargon i sin nye udenrigspolitik, men ingen magt at stille bag sine intentioner. Læsningen var vel, at Rusland - når man kom sig over tabet af Sovjet-imperiet - nok skulle komme til fornuft og blive en del af den europæiske familie om end lidt i yderkanten.

\section{Primakov-doktrinen}

Primakov var en belæst og belært karrierediplomat, der i Sovjetunionens døende år også fik en rolle i politik, hvilket fortsatte i 1990'erne, hvor han senere beklædte premierministerposten under præsident Boris Jeltsin og forgæves med Moskvas daværende borgmester, Jurij Lushkov, udfordrende Putin med en fælles blok ved det parlamentsvalg i 1999, der gik forud for valget af Putin til præsident i 2000.

Primakov var en grå eminence $\mathrm{i}$ russisk udenrigspolitik og statsfilosofi med en klassisk og konservativ tilgang og at ligne med USA's tidligere udenrigsminister Henry Kissinger i status. Forud for udenrigsministerposten var han Ruslands særligt befuldmægtigede i den første Irakkrig i 1990'erne på

Skal Rusland langsigtet fastholde stormagtsstatus, så skal økonomien følge med verdens øvrige stormagter, og her ligger et tilsyneladende dilemma for Putin 4.0. grund af hans indgående indsigt i mellemøstlige spørgsmål.

De principper og målsætninger, som Primakov var instrumentel $i$ at formulere, havde for det første udgangspunkt i termen 'det nære udland', dvs. de tidligere sovjetrepublikker, som vi i dag - med undtagelse af de tre baltiske stater - kender som det, Ruslands opfatter som sin privilegerede interessesfære. Det er helt på linje med Monroe-doktrinen, hvor den tidligere amerikanske præsident James Monroe med adresse til Europa den 2. december 1823 i en tale gjorde klart, at the Americas - Nord- og Sydamerika - var de Forenede Staters interessesfære, og at Europa skulle holde snitterne for sig selv der.

For det andet havde de udenrigspolitiske principper fokus på de betydende russiske mindretal i de tidligere sovjetrepublikker, som den russiske udenrigspolitik havde et særligt ansvar for.

For der tredje ønskede man en multipolær og ikke en unipolær (læs: USA-ledet) verdensorden. Denne verdensorden ønskes styret efter internationale regler - i russisk sammenhæng må det ikke fejllæses som en videreudvikling af den liberale verdensorden opbygget af Vesten efter Anden Verdenskrig, men som en verdensorden, hvor denne verdens stormagter respektfuldt bygger en orden med hensyntagen til hinandens 'legitime interesser'. 
Den russiske opfattelse af verdensorden, og hvordan man bygger sikkerhed, er stormagtsfokuseret og har sine rødder tilbage til Wienerkongressen i 1814-15, hvor Rusland mødte op med nyfunden og -vunden stormagtsstatus efter sejren i 1812 over Napoleon. Begge begivenheder, der overraskede selv Ruslands konservative og slavofile zar Aleksander den Første.

Siden Wienerkongressen har Rusland følt en medfødt ret til at sidde med ved det største bord, og sådan så også Primakov på den sag, sådan som det udenrigs- og sikkerhedspolitiske establishment i Moskva gør det den dag i dag.

For det fjerde skulle russisk udenrigspolitik bidrage til økonomisk vækst (BNP). Den målsætning blev sidenhen, da olieindtægterne polstrede Rusland i 00'erne, slebet til og faldt så kortvarigt ud efter 2014, hvor dramatiske fald i olieprisen og vestlige sanktioner satte russisk økonomi år tilbage. Men den er nu i forbindelse med præsident Putins 4. periode i år som præsident kommet tilbage blandt de udenrigspolitiske målsætninger.

Forklaringen er enkel - skal Rusland langsigtet fastholde stormagtsstatus, så skal økonomien følge med verdens øvrige stormagter, og her ligger et tilsyneladende dilemma for Putin 4.0, som jeg vender tilbage til.

\section{Rusland i verdensøkonomien}

Rusland har ikke en rolle i verdens$ø$ konomien som USA, hvor helt centrale institutioner som $\mathrm{fx}$ betalingsoverførselssystemet, SWIFT, er amerikansk domineret. USA kan lam- me Rusland ved udelukkelse; Rusland har intet alternativ.

Rusland er heller ikke på en vækstkurs som Kina, der - hvis den lineære udvikling forsætter (hvad lineære trends aldrig gør uendeligt, hverken $\varnothing$ konomisk eller politisk) - om nogle årtier bliver verdens største økonomi og overtager den rolle fra USA. Og Rusland har aldrig spillet en central rolle i udviklingen af det internationale handelssystem. Ruslands grå magt er ikke et match til USA og Kinas $\varnothing$ konomiske roller i verden, og derfor er den ikke et globalt anvendeligt instrument.

Men Ruslands grå magt er forsat et rimeligt godt match til Ruslands egen baggård, 'det nære udland'. For det første har disse lande typisk handelsrelationer, hvor Rusland er blandt de vigtigste, hvis ikke den vigtigste handelspartner.

For det andet har flere af disse lande aktuelt eller blot som en livsforsikring brug for Ruslands sikkerhedsgaranti, som Danmark har for USA's - blot mere akut.

Et ekstremt eksempel er Armenien, der ligger omkranset uden adgang til hav af Tyrkiet (historisk fjende siden det armenske folkedrab 1915-17 og i dag med en hermetisk lukket grænse), Iran (den anden regionale stormagt i området), Aserbajdsjan (konflikt omkring enklaven Nagorno-Karabakh, der i 30 år har kørt på vågeblus) samt Georgien mod nord - de to sidste også en del af Ruslands 'nære udland'.

For det tredje er landene i bedste fald umodne demokratier, med mere typisk autoritære styrer opbygget i 
I relation til Kina og Indien giver det ikke mening at tale om grå magt, fordi magtrelationen enten er mere ligeværdig eller ikke i Ruslands favør.

nogle tilfælde både omkring personkult og familie/klandynasti.

Og slutteligt er der - til nu - dybest set ikke andre, der vil investere politisk i disse lande, som Rusland vil. EU har et naboskabsprogram for Hviderusland, Ukraine, Georgien, Aserbajdsjan og Armenien - det er en vigtig støtte, men slet ikke tilstrækkeligt magtfuldt til, at disse lande kan basere sikkerhed eller regimeform på den. 'Stan'erne' - Kasakhstan, Usbekistan, Tadsjikistan m.v. - i Centralasien interesserer ikke EU og kun sporadisk USA, men i stigende grad Kina.

\section{Den grå magt og det nære udland}

Alt $i$ alt har Ruslands relative økonomiske magt matchet det nære udland i Ruslands favør siden Sovjetunionens sammenbrud. Ikke at landene ikke rækker hånden ud internationalt og bygger andre alliancer for at $\varnothing g e$ frihedsgraderne internationalt - det gør de alle. Men med undtagelse af Georgien 2008 og Ukraine 2014 så har alle lande mestret en balanceret kurs, hvor man retter ind efter Moskva, som man fornemmer nødvendigt, og rækker ud efter resten af verden, som man føler mod til.

Den grå magt udøves både som gulerod og pisk. Særligt Georgien har - både før og efter 2008 - oplevet økonomiske sanktioner fra russisk side, og de har ført til en vis disciplinering i Moskvas øjne. Og Ukraine er
- med statssammenbrud, Krim og Østukraine i 2014 - 'pilotprojektet' for Ruslands grå magt i 'det nære udland'. Ukraine er for Rusland - af alle årsager - langt det vigtigste af landene i regionen.

Rusland fører det samme 'waiting game', som Georgien har oplevet - filosofien er, at vi med tiden nok skal få jer tilbage i folden, og tid har vi nok af. Både Rusland og Ukraine fører sanktionskrig mod hinanden, men har stadig betydelig samhandel - i 2017 var Rusland forsat Ukraines vigtigste samhandelspartner.

I 2019 er der både præsident- og parlamentsvalg i Ukraine, og alt tyder på en markant ny magtkonfiguration. Ikke nødvendigvis én, der vil styrke Rusland, men den russiske tankegang er, at Ukraine nok skal skifte kurs på et tidspunkt - at der en dag, som man har erfaret med blandt andet Georgien og Armenien, kommer en russiskforstående regering. Ruslands tidshorisont er lang i det 'waiting game', og både Krim og Østukraine skal forstås i det perspektiv.

\section{Gasvåbnet}

Uden for 'det nære udland' finder Ruslands grå magt også anvendelse. Indlysende i Syrien nu hvor den er kombineret med hård magt, og de to instrumenter tilsammen har været instrumentelle $i$ at bryde den internationale diplomatiske isolation, Rusland i 2014 endte i som følge af Ukraine-konflikten.

Men ellers er brugen af grå magt internationalt begrænset - simpelthen fordi redskabet ikke er stærkt uden for 


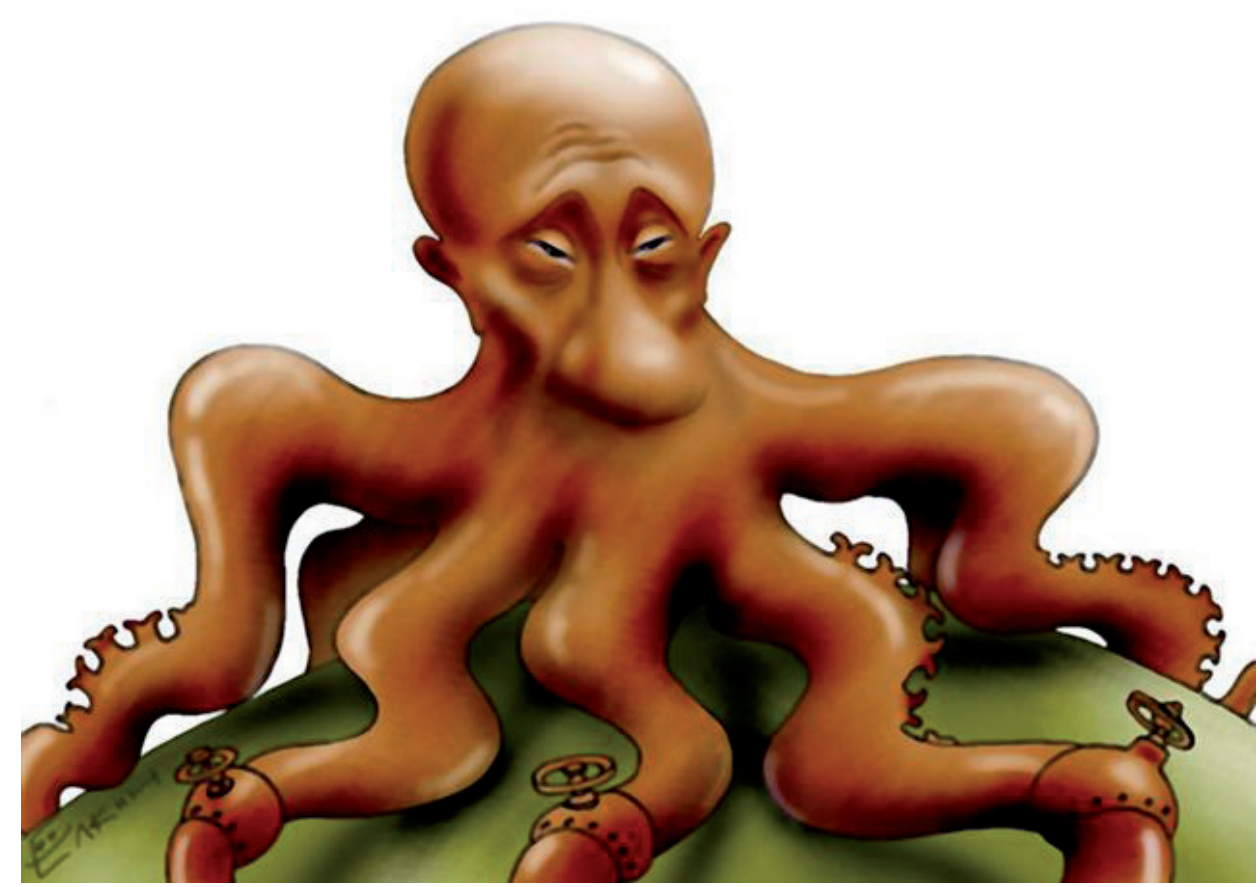

ILL.: Galandec via Flickr

det tidligere Sovjetunionen. Og oftest ender Rusland mere som en taktisk brik - som i de ovennævnte eksempler med Grækenland og Tyrkiet, hvor Rusland 'bruges' i et forsøg fra de respektive landes side på at øge politisk kapital over for henholdsvis EU/IMF og NATO.

I relation til Kina og Indien giver det ikke mening at tale om grå magt, fordi magtrelationen enten er mere ligeværdig eller ikke i Ruslands favør - men udenrigs-, sikkerheds- og samhandelspolitisk er begge lande vigtige for Rusland, som de regionale stormagter, de er.

Og dermed giver det mening at vende tilbage til det berømte og beryg- tede 'gas-våben'. Det gav kolde hjem i Sydøsteuropa i 2009 og har rammesat den politiske debat i Europa for Nord Stream 2, gasledningen i Østersøen fra Rusland til Tyskland, der skal supplere Nord Stream 1. Ledningen er ved at blive lagt, ergo den bliver til noget trods den standende debat.

Trump sagde under morgenmadssessionen ved NATO-topmødet i juli i år, at Tyskland var en fange af russisk gas (med Nord Stream 2 in mente), og der kan man jo spørge sig selv, om han har ret? Om Tysklands insisteren - mod de fleste allieredes position på Nord Stream 2 ender med et sikkerhedspolitisk problem for Tyskland og Europa? 
Svaret er nej. At svaret er nej, blokerer imidlertid ikke for, at man politisk kan finde projektet uklogt eller forkert, men det øger på ingen måde Ruslands greb om EU og Tyskland sikkerhedspolitisk.

Forklaringen har flere elementer, der dybest set handler om, at $2018 \mathrm{ik}$ ke er 2009. Og om at EU måske ikke storsælger sine politiske sejre i medierne, men har undergået en energipolitisk transformation, der i store træk har afmonteret det russisk gasvåben.

For det første har det europæiske gasmarked undergået en liberalisering, der begyndte før Ukraine-krisen. Ruslands/Gazproms ønskede markedsposition har altid været land-tilland-aftaler om langtidsaftaler med definerede priser knyttet til olieprisen. Det stillede Rusland \& Gazprom stærkt.

Liberaliseringen af det europæi-



Har Rusland et gasvåben i dag i forhold til Europa, så er det en vandpistol, der kan drille og genere, men ikke bruges til politisk afpresning. Gashistorien er i virkeligheden en historie om liberal orden og institutioners sejr over grå magt.

ske gasmarked betyder, at gas i dag handles på børser (i hubs), hvor de to største er i Tyskland. EU's konkurrencekommissær Margrethe Vestagers sager mod Gazprom handler netop om den transition. Og når EU skruer på de juridiske skruer, så retter Gazprom historisk altid ind og opfører sig som en normal markedsaktør. Gashandel i Europa er gået fra primært at være på russiske betingelser til at være på europæiske - og den trend ser intet ud til at stoppe.

For det andet var et resultat af Ukraine-krisen, at EU dels igangsatte en proces om energisikkerhed, dels fik 'reverse-flow' (at gas ikke kun sendes én vej, men kan sendes frem og tilbage i samme rør) - det vil sige at Rusland i en konflikt lettere kan kobles af. Også andre tiltag, fx bedre gaslagringsfaciliteter, har fremmet uafhængigheden.

For det tredje betød det dramatiske fald i oliepriserne i 2014 to ting - dels blev gasprisen afkoblet fra olieprisen, dels kom der en hel ny struktur på energi-mix i købers favør. Det suppleres af den grønne omstilling, som EU har i proces oven i hatten.

Det europæiske marked for gas for Rusland er gået fra at være sælgers marked til at være købers marked, og intet tyder på, at sælger kan komme tilbage i en dominerende rolle. Har Rusland et gasvåben i dag i forhold til Europa, så er det en vandpistol, der kan drille og genere, men ikke bruges til politisk afpresning. Gashistorien er i virkeligheden en historie om liberal orden og institutioners sejr over grå magt.

\section{Ukraine}

Men kan Ukraine ikke miste sine transitindtægter, når Nord Stream 2 bliver operationel?

Jo, det er en mulighed, men der er også politiske muligheder - som Tysklands kansler Merkel har været inde på - for at sikre disse i en politisk aftale med Rusland. Ukraines transi- 
tindtægter fra russisk gas - som det vigtigste transitland til EU - må også snart give anledning til europæisk refleksion.

Set i prismet af Ukraine-krisen i 2014 bruger Rusland gas til at presse Ukraine 'hjem', men prismet i 2009, da gassen ikke nåede til Sydøsteuropa, var i EU, at Europa ikke længere skulle være forsyningsmæssigt afhængig af Kiev og Moskvas gasslagsmål.

Det dilemma, der sjældent har været til offentlig refleksion siden 2014, er, om det er klogt af Ukraine at forblive afhængig af russiske transitindtægter fra gas og bede europæerne kæmpe den kamp for Ukraine. Ruslands 'waiting game' er baseret på, at Rusland til dato er Ukraines største samhandelspartner, og at Rusland har mere tålmodighed med den politiske udvikling i Ukraine end (Rusland tror) EU vil ende med at have.

For Rusland er både Ukraine-konflikten og den nye verdensorden, som vi ser forme sig, en udfordring for Ruslands grå magt. Vestens sanktioner mod Rusland napper i hvert fald et procentpoint af Ruslands BNP-vækst årligt. Det skader Ruslands mulighed for at holde sig i 'stormagts-klassen' på langt sigt og øger sandsynligheden for at være afhængig af en større magt. Som konsekvens er Rusland kastet i Kinas arme - det går rigtig godt politisk lige nu, men som en ven ved den russiske udenrigspolitiske tænketank RIAC sagde til mig i september, så følger de økonomiske resultater slet ikke med. Putins Rusland vil gerne kunne balancere mellem Europa og Asien og høste investeringer begge steder fra, men realiteten er, at Putin ikke selv kan løse sin konflikt med Vesten og heller ikke anvende grå magt i Kina.

Ruslands aktuelle dilemma er, at man hverken kan vælge øst eller vest til på egne præmisser. 